\title{
Silicas Chemically Modified with Sulfur-Containing Groups for Separation and Preconcentration of Precious Metals Followed by Spectrometric Determination
}

\author{
Vladimir Losev ${ }^{1}$, Evgeney Elsuf'ev ${ }^{2}$, Elena Borodina ${ }^{1} \mathbb{(}$, Olga Buyko $^{1, * \mathbb{C}}$, Natalya Maznyak $^{1}$ \\ and Anatoliy Trofimchuk ${ }^{3}$ \\ 1 Scientific Research Engineering Center "Kristall”, Siberian Federal University, 660041 Krasnoyarsk, Russia; \\ losevvn@gmail.com (V.L.); crilenka@gmail.com (E.B.); nmaznyak@sfu-kras.ru (N.M.) \\ 2 Institute of Chemistry and Chemical Technology SB RAS, \\ Federal Research Center "Krasnoyarsk Science Center SB RAS", 660036 Krasnoyarsk, Russia; \\ yelsufyevev@gmail.com \\ 3 Department of Inorganic Chemistry, Taras Shevchenko National University of Kyiv, 01033 Kyiv, Ukraine; \\ aktrof@svitonline.com \\ * Correspondence: obuyko@sfu-kras.ru
}

\section{check for}

updates

Citation: Losev, V.; Elsuf'ev, E.; Borodina, E.; Buyko, O.; Maznyak, N.; Trofimchuk, A. Silicas Chemically Modified with Sulfur-Containing Groups for Separation and

Preconcentration of Precious Metals Followed by Spectrometric

Determination. Minerals 2021, 11, 481

https://doi.org/10.3390/

$\min 11050481$

Academic Editor: Francisco Franco

Received: 8 March 2021

Accepted: 26 April 2021

Published: 30 April 2021

Publisher's Note: MDPI stays neutral with regard to jurisdictional claims in published maps and institutional affiliations.

Copyright: (c) 2021 by the authors. Licensee MDPI, Basel, Switzerland. This article is an open access article distributed under the terms and conditions of the Creative Commons Attribution (CC BY) license (https:// creativecommons.org/licenses/by/ $4.0 /)$.

\begin{abstract}
Silicas chemically modified with a number of sulfur-containing groups (mercaptopropyl, mercaptophenyl, dipropyl disulfide, thiadiazole thiol, dithiocarbamate and thiourea derivatives) were proposed for the separation and preconcentration of precious metals. These adsorbents quantitatively extracted precious metals from 0.5 to $4 \mathrm{M}$ solutions of hydrochloric acid. It allowed their separation from high concentrations of non-ferrous, alkaline earth, alkali and some other related metals. The selectivity of separation of kinetically labile precious metal ions in ligand substitution reactions from kinetically inert ones depended on the nature of sulfur atom within the functional group of adsorbents and increased when passing from thione to thiol sulfur. Approaches for the preconcentration of precious metals using silicas chemically modified with sulfur-containing groups prior to their AAS, ICP-OES, and ICP-MS determination in ores, concentrates and their processing products were proposed. The correctness of the developed methods was confirmed by the analysis of certified reference materials.
\end{abstract}

Keywords: chemically modified silicas; sulfur-containing groups; precious metals; separation; preconcentration; determination; AAS; ICP-OES; ICP-MS

\section{Introduction}

Due to their unique properties, the platinum metals are widely used in various fields of science and technology. In the environment, the platinum metals are found in low concentrations in the presence of high concentrations of accompanying elements. Spectrometric methods of analysis are mainly used to determine trace components in objects of various composition.

Direct analysis of the solutions obtained after the decomposition of geological materials for the content of the platinum group metals is difficult due to the overlapping of spectral lines of elements in atomic absorption (AAS) and optical emission spectrometry (OES). The easily ionized alkali and alkaline earth metals present in the solution reduce the intensity of the spectral lines of the analytes. The results of the determination of precious metals by inductively coupled plasma mass spectrometry (ICP-MS) are distorted due to polyatomic interferences of non-ferrous metals [1-3].

The use of preconcentration methods makes it possible to separate analytes from the predominant amounts of accompanying and interfering elements and to increase the selectivity of spectrometric methods. As a result of preconcentration and desorption, the 
analyzed solutions have a simple matrix of a known composition, which allows us to reduce the number of calibration standards.

The solid-phase extraction (SPE) method makes it possible to isolate a trace component on a relatively small mass of adsorbent from a large volume of solution, providing good separation efficiency and high preconcentration coefficients.

A number of adsorbents have been proposed for solid-phase extraction of precious metals; they are characterized by high capacity, good kinetics and exceptional selectivity. Adsorbents differ in matrices, nature of functional groups, capacities, particle size, and other ways. Adsorbents, depending on the nature of the functional groups, are divided into ion-exchange (cation exchangers, anion exchangers) and complexing (including chelating) adsorbents.

There are two possible options for using cation exchangers for separating platinum metals from accompanying ones. The first option is based on the separation of the matrix (ions of non-ferrous, alkali and alkaline earth metals from precious metals) from solutions of hydrochloric acid in which platinum metals are present in the form of negatively charged chloro complexes and are not extracted by cation exchangers [4]. The second option is based on the ability of some platinum metals to form cationic complexes (aqua complexes, complexes with ammonia, pyridine, etc.) and, accordingly, they can be extracted by cation exchangers [5,6]. The use of cation exchangers is ineffective, since to remove the predominant amounts of cations of non-ferrous and other accompanying metals, it is necessary to use a lot of cation exchanger, and the separation of cationic complexes of precious metals from cations of accompanying metals is a complex task.

It is most advisable to use adsorbents that allow the separation of trace amounts of precious metals from solutions with a high content of accompanying elements.

The use of anion exchangers for the separation of precious metals from base metals in hydrochloric acid solutions is based on the ability of chloride complexes of precious metals to be retained by strongly basic anion exchangers with groups of quaternary ammonium, phosphonium, pyridinium bases [7-9]. Adsorbents with primary, secondary and tertiary amines, depending on the acidity of the medium, can act both as anion exchangers and as complexing adsorbents [10-13].

The use of N, S- and N-containing adsorbents of various natures for the preconcentration and separation of platinum metals was considered in [14-18]. When considering the adsorbents proposed for the preconcentration of precious metals, there is a tendency to create adsorbents with the highest possible selectivity, which was the reason for the passing from nitrogen- to nitrogen- and sulfur-, and further to sulfur-containing adsorbents.

Sulfur-containing functional groups of adsorbents, in contrast to nitrogen-containing groups, are less sensitive to the anionic composition of solutions and bind a narrow range of metal ions. Precious metals in acidic solutions form much stronger complexes with sulfur-containing groups than non-ferrous and other accompanying metals. Non-ferrous metal ions forming insoluble sulfides are bound by sulfur-containing groups in weakly acidic, neutral or weakly alkaline media, which makes it possible to effectively separate platinum metals from them by solid-phase extraction in acidic media [19-21]. It should be noted that the sulfur-containing groups of adsorbents are also less sensitive to the composition of the inner coordination sphere of the complexes of precious metals than nitrogen-containing ones. They extract precious metals with equal efficiency both from 2 to $4 \mathrm{M}$ solutions of hydrochloric acid, in which precious metals exist in the form of chloride complexes, and from dilute solutions of hydrochloric acid (0.1-1 M), in which precious metals exist in the form of aquachloride complexes of various composition.

In this regard, adsorbents based on silicas chemically modified with sulfur-containing groups are of particular interest. Due to silicon oxide matrix these adsorbents do not swell in aqueous solutions, and possess enough mechanical strength and hydrolytic stability in acidic and slightly alkaline media. Due to the surface arrangement of functional groups chemically modified silicas (CMS) are characterized by good kinetics and adsorbed elements are easy to elute. 
The success of using organic reagents with thionic or thiol sulfur in liquid extraction $[22,23]$ and solid-phase extraction of precious metals using polymer adsorbents with sulfur-containing groups [24-26] was the reason for the synthesis and study of adsorbents based on silica chemically modified with sulfur-containing functional groups.

In this work, we investigated CMS with sulfur-containing functional groups (mercaptopropyl, dipropyldisulfide, dithiocarbamate, thiodiazolethiol, mercaptophenyl and thiourea derivatives groups) to separate and preconcentrate precious metals and to study the effect of the nature of sulfur in the functional groups fixed on the silica surface.

These functional groups fixed on the silica surface were chosen because thiourea and its derivatives, as well as dithiocarbamates, are widely used in liquid extraction of precious metals [27-30]. Reagents containing thiol sulfur are more selective than reagents containing thionic or sulfide sulfur [31,32].

Sulfur-containing groups, in particular mercaptopropyl, can be oxidized [33] to dipropyldisulfide groups. Therefore, we studied the solid-phase extraction of elements with adsorbents containing on the silica surface the oxidized form of the ligand-dipropyldisulfide groups.

\section{Materials and Methods}

\subsection{Reagents}

Stock solutions of $\mathrm{Au}^{3+}, \mathrm{Pd}^{2+}, \mathrm{Pt}^{2+}, \mathrm{Pt}^{4+}, \mathrm{Rh}^{3+}, \mathrm{Ir}^{4+}, \mathrm{Ru}^{4+}, \mathrm{Os}^{4+}\left(1.0 \mathrm{mg} \cdot \mathrm{mL}^{-1}\right)$ were prepared by dissolving commercially available $\mathrm{H}\left[\mathrm{AuCl}_{4}\right] \cdot 4 \mathrm{H}_{2} \mathrm{O}, \mathrm{PdCl}_{2}, \mathrm{H}_{2}\left[\mathrm{PtCl}_{6}\right] \cdot 6 \mathrm{H}_{2} \mathrm{O}$, $\mathrm{H}_{2}\left[\mathrm{PtCl}_{4}\right] \cdot 2 \mathrm{H}_{2} \mathrm{O}, \mathrm{H}_{3}\left[\mathrm{RhCl}_{6}\right], \mathrm{Na}_{3}\left[\mathrm{IrCl}_{6}\right], \mathrm{RuCl}_{3}, \mathrm{H}_{2}\left[\mathrm{OsCl}_{6}\right]$.(JSC “Aurat", Russia) in $2.0 \mathrm{M}$ $\mathrm{HCl}$. Solutions of $\mathrm{Ru}^{4+}$ were prepared immediately before the experiment by oxidizing $\mathrm{Ru}^{3+}$ with hydrogen peroxide in $6 \mathrm{M} \mathrm{HCl}$. In order to prepare stock solution of $\mathrm{Ag}^{+}$with a concentration of $0.5 \mathrm{mg} \cdot \mathrm{mL}^{-1}$ in $6 \mathrm{M} \mathrm{HCl}$, an exact weighed portion of metallic silver (99.9\% grade) was dissolved in nitric acid, followed by conversion into $6 \mathrm{M} \mathrm{HCl}$.

Solutions of alkali, alkaline earth metals, $\mathrm{Fe}^{3+}, \mathrm{Al}^{3+}, \mathrm{Cu}^{2+}, \mathrm{Pb}^{2+}, \mathrm{Zn}^{2+}, \mathrm{Mn}^{2+}, \mathrm{Ni}^{2+}$, $\mathrm{Co}^{2+}$, and $\mathrm{Fe}^{2+}$ were prepared by dissolving the corresponding salts (Reachim, Ufa, Russia) in $0.1 \mathrm{M} \mathrm{HCl}$. Solutions with a lower concentration of metal ions were prepared by diluting the stock solutions.

ICP Multi-element standard USP-III ( $\mathrm{Ir}, \mathrm{Os}, \mathrm{Pd}, \mathrm{Pt}, \mathrm{Rh}, \mathrm{Ru}$ ) purchased from Merck KGaA (Merck, Darmstadt, Germany), 10-51-1 (Ag), 10-70-2 (Os) purchased from highpurity standards (High-Purity Standards, North Charleston, SC, USA) were used as a calibration standards for determination of precious metals. ICP-MCS-1 (As, Be, B, Cd, Pb, Mn, Se, Zn), ICP-MCS-8 (Al, Ca, Cr, Li, Ni, K, Na, and Sr), ICP-MCS-10 (Al, Ba, Be, Co, $\mathrm{Cu}, \mathrm{Fe}, \mathrm{V})$ were used as calibration standards for ICP-OES and ICP-MS determination of accompanying metals. The standards were purchased from high-purity standards (High-Purity Standards, North Charleston, SC, USA).

Analytical grade reagents $\mathrm{HF}, \mathrm{HClO}_{4}, \mathrm{HCl}, \mathrm{HNO}_{3}, \mathrm{NaOH}$, thiourea (Reachim, Ufa, Russia) were used. Hydrochloric and nitric acids of reagent grade were purified by distillation using distillacid ${ }^{\mathrm{TM}}$ BSB-939-IR (Berghof, Eningen, Germany). Solutions of lower concentrations were prepared by dilution of concentrated acids with deionized water. Deionized water $\left(18.3 \mathrm{M} \Omega \cdot \mathrm{cm}^{-1}\right)$ was prepared using E-pure D4642-33 (Barnstead International, Dubuque, IA, USA).

The required $\mathrm{pH}$ was adjusted by adding of $1 \mathrm{M}$ solutions of $\mathrm{NaOH}$ or $\mathrm{HCl}$ dropwise. The eluent $(5 \%$ or $10 \%(w / w)$ thiourea solution in $1.0 \mathrm{M} \mathrm{HCl})$ was prepared by dissolving a weighed portion of thiourea in $1.0 \mathrm{M} \mathrm{HCl}$.

Silica gel 60 (particle size of $0.10-0.16 \mathrm{~mm}$, specific surface area of $270 \mathrm{~m}^{2} \cdot \mathrm{g}^{-1}$, an average pore size of $\sim 12 \mathrm{~nm}$ ) purchased from Merck (Germany) was used as a matrix for the adsorbents synthesis.

$\gamma$-aminopropyltriethoxysilane, allyl isothiocyanate, ethyl isothiocyanate, benzoyl isothiocyanate, phenyl isothiocyanate, $\gamma$-mercaptopropyltrimethoxysilane, $\gamma$-(triethoxysilane)propyl isocyanate, 4-aminothiophenol, 2-aminothiocyanate, carbon disulfide purchased from Aldrich and 2-amino-1,3,4-thiodiazole-2-thiol purchased from Fluka were used as silica surface modifiers. 


\subsection{Instrumentation}

Metal content in the solutions was determined by ICP-OES, ICP-MS, flame atomic absorption spectrometry (FAAS), and graphite furnace atomic absorption spectrometry (GFAAS) analyses of an aqueous phase using iCAP 6500 Duo, Xseries II and Solaar 6M by Thermo Scientific (Waltham, MA, USA). The instruments' operational conditions are represented in Tables S1-S3.

The $\mathrm{pH}$ measurements were carried out with a SevenEasy pH Meter S20 (Mettler-Toledo, Greifensee, Switzerland) equipped with combined electrode InLabExpertPro. A Masterflex L/S peristaltic pump (Cole-Parmer Instruments Company, East Bunker Ct Vernon Hills, IL, USA) was used for pumping fluids through the mini-column packed with an adsorbent. Glass mini-column or thermostated glass minicolumn (i.d. of $3 \mathrm{~mm}$, height of $10 \mathrm{~cm}$ ) was used for preconcentration of metal ions in dynamic mode. Muffle furnace SNOL 6/10-V (TECHNOTHERM, Istra, Russia) was used for the geological samples firing.

The solutions were heated in glass thermostated columns connected to a UTU-2 thermostat (Horyzont, Krakow, Poland). The solutions were mixed using a WU-4 shaker (Horyzont, Krakow, Poland).

\subsection{Synthesis of the Adsorbents}

There are several approaches to the synthesis of sulfur-containing CMS. The first approach is based on the interaction of organosilicon modifiers with silica in an organic solvent, such as toluene [34,35]. It was used for the synthesis of the MPS adsorbent [36].

The second approach is based on the chemical "assembly" of the functional group on the silica surface and was used in the synthesis of an adsorbent with dithiocarbamate groups (DTCS): the previously synthesized aminopropyl silica gel was treated with carbon disulfide [37].

The third approach is based on the synthesis of a modifier in an organic solvent by the interaction of a reagent containing the required functional group with triethoxysilanes and subsequent fixation of the resulting modifier on the silica surface. For example, the preparation of chemically modified silicas with groups of thiourea derivatives (ATUS, ETUS, BTUS, PhTUS) is based on the fixation on the silica surface of a modifier previously synthesized in an organic solvent by the interaction of $\gamma$-aminopropyltriethoxysilane with the corresponding isothiocyanates $\mathrm{RN}=\mathrm{C}=\mathrm{S}$ (where $\mathrm{R}$ is allyl, ethyl, benzoyl, phenyl). An adsorbent with thiodiazolethiol groups (TDTS) was synthesized by fixing on the surface of silica gel a modifier previously prepared in an organic solvent by the interaction of $\gamma$ (triethoxysilane)-propyl isocyanate with 2-amino-1,3,4-thiodiazole-2-thiol. The preparation of silicas with mercaptophenyl and aminobenzothiazole groups (MPhS, ABTS) was carried out in a similar manner, but for the reaction with $\gamma$-(triethoxysilane)propyl isocyanate, 4-aminothiophenol and 2-aminothiophenol were used, respectively.

The fourth approach for obtaining sulfur-containing CMS is the chemical transformation of fixed sulfur-containing groups. For example, the DSS adsorbent was prepared by oxidizing the mercapropyl groups fixed on the silica surface to dipropyldisulfide groups with iodine. The characteristics of the synthesized adsorbents are represented in Table 1. 
Table 1. Silicas chemically modified with sulfur-containing groups.

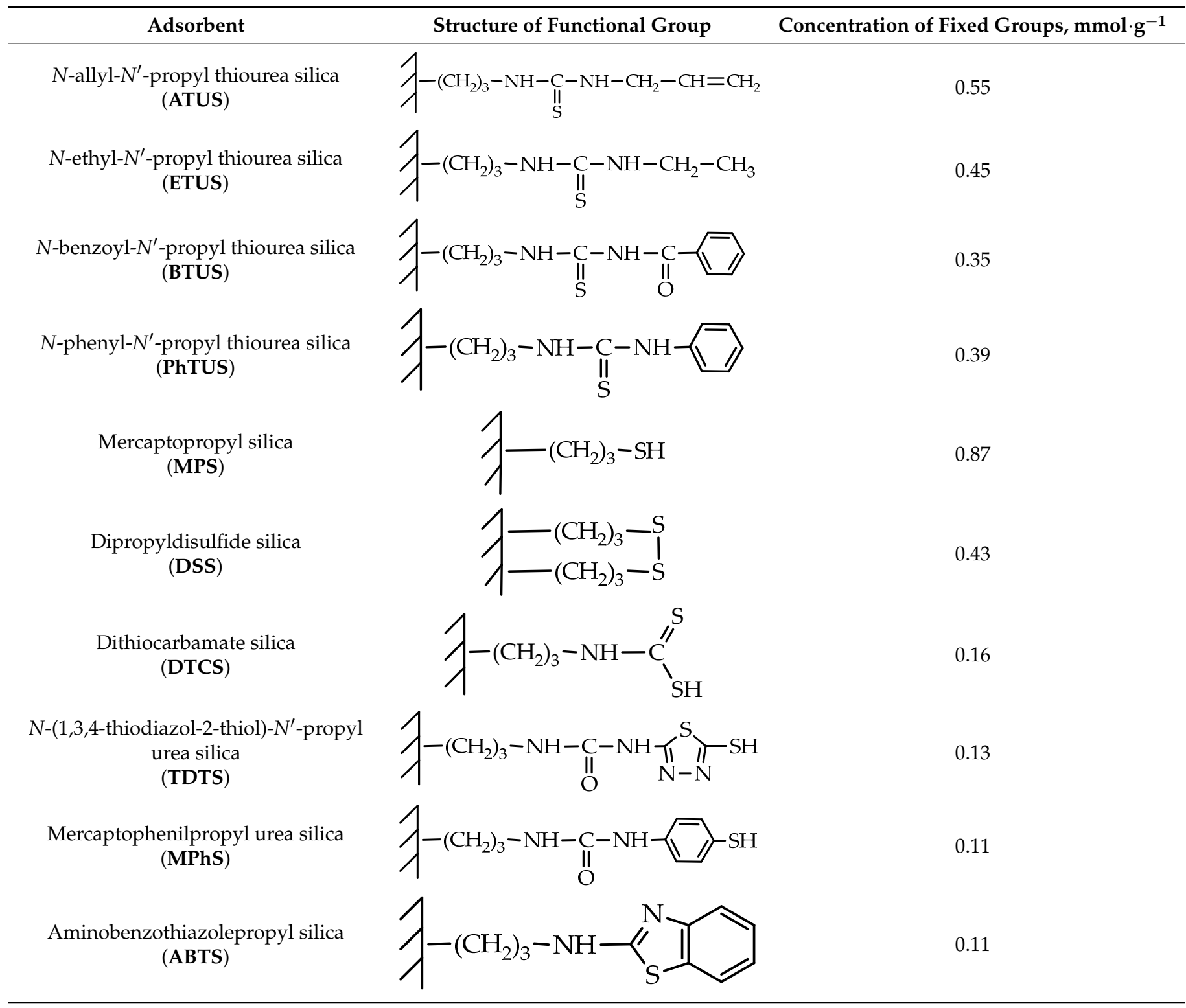

\subsection{Batch Procedure}

In the batch experiment $10.0 \mu \mathrm{g}$ of metal ion as a solution in $0.5-4.0 \mathrm{M} \mathrm{HCl}$ was placed into a thermostated test tube; $\mathrm{HCl}$ or $\mathrm{NaOH}$ was added to adjust required acidity; and deionized water was added to a total volume of $10.0 \mathrm{~mL}$. The adsorbent mass of $0.100 \mathrm{~g}$ was added; the tube was stopped and stirred for $1-60 \mathrm{~min}$ at $20^{\circ} \mathrm{C}$ or $95^{\circ} \mathrm{C}$. In the study of adsorption of kinetically inert platinum metals at $95^{\circ} \mathrm{C}, 1.0 \mathrm{~mL}$ of a $0.025 \mathrm{M} \mathrm{SnCl}_{2}$ solution was added. The solution was separated from the adsorbent by decantation. For desorption of precious metals, $10.0 \mathrm{~mL}$ of a $10 \%(w / w)$ solution of thiourea in $1.0 \mathrm{M} \mathrm{HCl}$ was added to the adsorbent and stirred for $1 \mathrm{~min}-60 \mathrm{~min}$ at $20^{\circ} \mathrm{C}$ or $95^{\circ} \mathrm{C}$. The distribution of the metal was monitored by the analysis of aqueous phase by ICP-OES.

\subsection{Column Procedure}

The study of adsorption of precious metals in the dynamic mode was carried out at $20{ }^{\circ} \mathrm{C}$ by passing of $10.0 \mathrm{~mL}$ of a solution containing $10.0 \mu \mathrm{g} \cdot \mathrm{mL}^{-1}$ of a precious metal ion through a column (height of $5 \mathrm{~cm}$, i.d. of $3 \mathrm{~mm}$ ) containing $0.1 \mathrm{~g}$ of adsorbent with a flow rate 
of $1.0 \mathrm{~mL} \mathrm{~min}^{-1}$. To elute retained precious metals, $10.0 \mathrm{~mL}$ of a $10 \%(w / w)$ thiourea solution in $1 \mathrm{M} \mathrm{HCl}$ at $20^{\circ} \mathrm{C}$ was passed through the column at a flow rate of $1.0 \mathrm{~mL} \mathrm{~min}{ }^{-1}$.

The study of adsorption of $\mathrm{Rh}^{3+}, \mathrm{Ir}^{4+}, \mathrm{Ru}^{4+}$, and $\mathrm{Os}^{4+}$ in the dynamic mode was carried out at $95^{\circ} \mathrm{C}$ by passing of $10.0 \mathrm{~mL}$ of a solution containing $10.0 \mu \mathrm{g} \cdot \mathrm{mL}^{-1}$ of a precious metal ion and $0.0025 \mathrm{M} \mathrm{SnCl}_{2}$ through a thermostated column containing $0.1 \mathrm{~g}$ of adsorbent with a flow rate of $1.0 \mathrm{~mL} \cdot \mathrm{min}^{-1}$. To desorb these precious metals, $10.0 \mathrm{~mL}$ of a $10 \%(w / w)$ thiourea solution in $1.0 \mathrm{M} \mathrm{HCl}$ at $95^{\circ} \mathrm{C}$ was passed through the column at a flow rate of $1.0 \mathrm{~mL} \cdot \mathrm{min}^{-1}$.

The separation of kinetically labile chloride complexes of precious metals from kinetically inert ones and their preconcentration was carried out using a system of two sequentially connected mini-columns containing $0.1 \mathrm{~g}$ of adsorbent in each. On the first column at $20{ }^{\circ} \mathrm{C}$, the kinetically labile chlorocomplexes $\mathrm{Au}^{3+}, \mathrm{Pd}^{2+}, \mathrm{Pt}^{4+}$ were retained. $\mathrm{SnCl}_{2}$ solution was added in the stream after the first column. Then, the solution was passed through the second thermostated column at $95^{\circ} \mathrm{C}$. On the second column, adsorption of kinetically inert complexes of $\mathrm{Rh}^{3+}, \mathrm{Ir}^{4+}, \mathrm{Ru}^{4+}, \mathrm{Os}^{4+}$ occurred. The desorption of retained precious metals was carried out by passing of $10.0 \mathrm{~mL} 10 \%(w / w)$ thiourea solution in 1.0 $\mathrm{M} \mathrm{HCl}$ through each column with the flow rate of $1.0 \mathrm{~mL} \cdot \mathrm{min}^{-1}$ : at $20^{\circ} \mathrm{C}$ through the first column and $95^{\circ} \mathrm{C}$ through the second one.

\subsection{Sample Preparation}

We have developed a method for digestion of geological samples and their processing products, which made it possible to use a general approach for the digestion of materials of various composition containing precious metals.

Geological samples and products of their processing were placed in a glassy carbon crucible and pre-dried at $105^{\circ} \mathrm{C}$. Then, sample portions of $1.0000 \mathrm{~g}$ were roasted in a muffle furnace for $2 \mathrm{~h}$ at $500{ }^{\circ} \mathrm{C}$. After cooling, the roasted sample was moistened with deionized water, then $25.0 \mathrm{~mL}$ conc. $\mathrm{HF}$ and $2.0 \mathrm{~mL} \mathrm{H}_{2} \mathrm{SO}_{4}$ (diluted 1:1) were added. The digestion was carried out under slow heating until sulfuric anhydride vapors appeared. Then, $30.0 \mathrm{~mL}$ mixture of acids $\mathrm{HF}: \mathrm{HClO}_{4}: \mathrm{HCl}_{\mathrm{HNO}} \mathrm{HN}_{3}$ (2:2:3:3) was added; the digestion was carried out under heating, and mixture of acids was evaporated to dryness. Then, $30.0 \mathrm{~mL}$ mixture of acids $\mathrm{HCl}: \mathrm{HNO}_{3}$ (3:1) was added to sample and evaporated to wet salts. We added $10.0 \mathrm{~mL}$ of concentrated $\mathrm{HCl}$ to the residue and evaporated to wet salts; the procedure was repeated twice. Afterwards, $20.0 \mathrm{~mL}$ of concentrated $\mathrm{HCl}$ and $20.0 \mathrm{~mL}$ of deionized water was added, and salts were dissolved under heating $\left(50{ }^{\circ} \mathrm{C}\right)$. If an insoluble precipitate was present, which contains ruthenium, osmium, iridium, and rhodium, it was filtered through a paper filter, the filter with the precipitate was placed in a corundum crucible and turned to ash. A fivefold excess of sodium peroxide was added to the ash residue, the mixture was stirred and fused at $650{ }^{\circ} \mathrm{C}$ for $20 \mathrm{~min}$. The melt was leached with $20 \mathrm{~mL}$ of $2 \mathrm{M} \mathrm{HCl}$. The solutions were joined together, transferred into a $100 \mathrm{~mL}$ volumetric flask and diluted with $2.0 \mathrm{M} \mathrm{HCl}$ to the mark.

\section{Results and Discussion}

3.1. Solid-Phase Extraction of Platinum Group Metals, $\mathrm{Ag}^{+}$and $\mathrm{Au}^{3+}$, and Non-Ferrous Metals Using Silicas Chemically Modified with Sulfur-Containing Groups

The efficiency of using CMS with sulfur-containing groups for the preconcentration of precious metals, first of all, depends on the conditions of the extraction of the nonferrous and other accompanying metals. This determines the conditions for their separate extraction. Silicas, chemically modified with sulfur-containing groups, extracted nonferrous metals from weakly acidic, neutral and weakly alkaline solutions (Figure S1); the time of the attainment of adsorption equilibrium did not exceed $5 \mathrm{~min}$. Calcium(II), magnesium(II), strontium(II), aluminum(III) and alkali metals were not extracted by sulfurcontaining silicas in a wide $\mathrm{pH}$ range from 1 to 9.

DSS adsorbent extracted non-ferrous metal ions at higher $\mathrm{pH}$ values than MPS adsorbent (Figure S1); in addition, the extraction of some metals was not quantitative. 
Chloride complexes of precious metals are divided into kinetically labile $\left(\mathrm{Ag}^{+}, \mathrm{Au}^{3+}\right.$, $\left.\mathrm{Pd}^{2+}, \mathrm{Pt}^{2+}, \mathrm{Pt}^{4+}\right)$ and kinetically inert complexes $\left(\mathrm{Rh}^{3+}, \mathrm{Ir}^{4+}, \mathrm{Ru}^{4+}\right.$ and $\left.\mathrm{Os}^{4+}\right)$ in reactions of ligand substitution.

Most of the studies are devoted to the SPE of $\mathrm{Au}^{3+}, \mathrm{Pd}^{2+}, \mathrm{Pt}^{2+}$, and $\mathrm{Pt}^{4+}$, which are kinetically labile in the reactions of ligand substitution; the adsorption of kinetically inert $\mathrm{Rh}^{3+}, \mathrm{Ir}^{4+}, \mathrm{Ru}^{4+}, \mathrm{Os}^{4+}$ remains without attention as a rule.

Solid-phase extraction of precious metals should be carried out from dilute solutions of hydrochloric acid (0.5-4 M), since accompanying non-ferrous and other metals are extracted from weakly acidic and weakly alkaline solutions; their noticeable extraction was observed at $\mathrm{pH}>3$ (Figure S1). In addition, in weakly acidic and neutral solutions, aquation and hydrolysis of chloro complexes of platinum group metals occurs. In hydrochloric acid solutions (after liquid-phase oxidative decomposition of natural and industrial samples) precious metals are represented by chloride complexes in the following oxidation states: $\mathrm{Ag}^{+}, \mathrm{Au}^{3+}, \mathrm{Pd}^{2+}, \mathrm{Pt}^{4+}, \mathrm{Rh}^{3+}, \mathrm{Ir}^{4+}, \mathrm{Ru}^{4+}, \mathrm{Os}^{4+}$.

When preconcentrating platinum group metals, it is also necessary to take into account the extraction of $\mathrm{Ag}^{+}$and $\mathrm{Au}^{3+}$, which interact with sulfur-containing groups of adsorbents under similar conditions as kinetically labile chloro complexes of platinum group metals. All studied adsorbents quantitatively extracted $\mathrm{Au}^{3+}$ from 0.5 to $4 \mathrm{M} \mathrm{HCl}$ at room temperature. The DTCS and DSS adsorbents did not extract $\mathrm{Ag}^{+}$from hydrochloric acid solutions, which can be used to separate $\mathrm{Au}^{3+}$ and other platinum group metals from it.

The conditions for the quantitative extraction of platinum metals from hydrochloric acid solutions by silicas chemically modified with sulfur-containing groups are given in Table 2. As can be seen from the table, all the studied adsorbents (except ABTS) extracted $\mathrm{Pd}^{2+}$ in a wide range of hydrochloric acid concentrations at room temperature with a time of attainment of adsorption equilibrium from $2 \mathrm{~min}$ to $5 \mathrm{~min}$. For the quantitative extraction of $\mathrm{Pd}^{2+}$ with the ABTS adsorbent, heating to $95^{\circ} \mathrm{C}$ and the phase contact time of $30 \mathrm{~min}$ were required.

Table 2. Conditions for the quantitative extraction of platinum group metals ions from hydrochloric acid solutions by silicas chemically modified with sulfur-containing groups.

\begin{tabular}{|c|c|c|c|c|c|c|c|}
\hline Adsorbent & $\mathrm{T},{ }^{\circ} \mathrm{C}$ & $\mathrm{Pd}^{2+}$ & $\mathrm{Pt}^{4+}$ & $\mathbf{R h}^{3+}$ & $\mathrm{Ir}^{4+}$ & $R \mathbf{u}^{4+}$ & $\mathrm{Os}^{4+}$ \\
\hline \multirow[b]{2}{*}{ ATUS } & 25 & $\begin{array}{c}0.5-6 \mathrm{M} \\
5 \mathrm{~min}\end{array}$ & $\begin{array}{c}0.5-4 \mathrm{M} \\
10 \mathrm{~min}\end{array}$ & - & - & - & - \\
\hline & 95 & $\begin{array}{c}0.5-6 \mathrm{M} \\
5 \mathrm{~min}\end{array}$ & $\begin{array}{c}0.5-4 \mathrm{M} \\
10 \mathrm{~min}\end{array}$ & $\begin{array}{c}0.5-5 \mathrm{M} \\
10 \mathrm{~min}\end{array}$ & $\begin{array}{c}0.5-4 \mathrm{M} \\
10 \mathrm{~min}\end{array}$ & $\begin{array}{c}2-4 \mathrm{M} \\
10 \mathrm{~min}\end{array}$ & $\begin{array}{c}0.5-4 \mathrm{M} \\
30 \mathrm{~min} \\
\mathrm{SnCl}_{2}\end{array}$ \\
\hline \multirow[b]{2}{*}{ DTCS } & 25 & $\begin{array}{c}0.5-6 \mathrm{M} \\
5 \mathrm{~min}\end{array}$ & $\begin{array}{c}0.5-4 \mathrm{M} \\
5 \mathrm{~min}\end{array}$ & - & - & - & - \\
\hline & 95 & $\begin{array}{c}0.5-6 \mathrm{M} \\
5 \mathrm{~min}\end{array}$ & $\begin{array}{c}0.5-2 \mathrm{M} \\
5 \mathrm{~min}\end{array}$ & $\begin{array}{l}1-4 \mathrm{M} \\
5 \mathrm{~min} \\
\mathrm{SnCl}_{2}\end{array}$ & $\begin{array}{c}0.5-4 \mathrm{M} \\
30 \mathrm{~min}\end{array}$ & $\begin{array}{c}0.5-1 \mathrm{M} \\
40 \mathrm{~min} \\
\mathrm{SnCl}_{2}\end{array}$ & $\begin{array}{c}2-4 \mathrm{M} \\
60 \mathrm{~min} \\
\mathrm{SnCl}_{2}\end{array}$ \\
\hline \multirow[b]{2}{*}{ MPS } & 25 & $\begin{array}{c}0.5-6 \mathrm{M} \\
2 \mathrm{~min}\end{array}$ & - & - & - & - & - \\
\hline & 95 & $\begin{array}{c}0.5-6 \mathrm{M} \\
2 \mathrm{~min}\end{array}$ & $\begin{array}{c}0.5-5 \mathrm{M} \\
5 \mathrm{~min}\end{array}$ & $\begin{array}{c}0.5-5 \mathrm{M} \\
10 \mathrm{~min}\end{array}$ & $\begin{array}{c}0.5-4 \mathrm{M} \\
10 \mathrm{~min}\end{array}$ & $\begin{array}{l}2-6 \mathrm{M} \\
5 \mathrm{~min}\end{array}$ & $\begin{array}{c}0.5-4 \mathrm{M} \\
30 \mathrm{~min} \\
\mathrm{SnCl}_{2}\end{array}$ \\
\hline \multirow[b]{2}{*}{ DSS } & 25 & $\begin{array}{c}0.2-2 \mathrm{M} \\
15 \mathrm{~min}\end{array}$ & - & - & - & - & - \\
\hline & 95 & $\begin{array}{c}0.5-2 \mathrm{M} \\
15 \mathrm{~min}\end{array}$ & $\begin{array}{c}0.5-4 \mathrm{M} \\
20 \mathrm{~min}\end{array}$ & $\begin{array}{c}0.5-4 \mathrm{M} \\
20 \mathrm{~min}\end{array}$ & $\begin{array}{c}0.5-4 \mathrm{M} \\
30 \mathrm{~min}\end{array}$ & $\begin{array}{l}4-6 \mathrm{M} \\
20 \mathrm{~min}\end{array}$ & $\begin{array}{c}0.5-4 \mathrm{M} \\
60 \mathrm{~min} \\
\mathrm{SnCl}_{2}\end{array}$ \\
\hline
\end{tabular}


Table 2. Cont.

\begin{tabular}{|c|c|c|c|c|c|c|c|}
\hline Adsorbent & $\mathrm{T},{ }^{\circ} \mathrm{C}$ & $\mathrm{Pd}^{2+}$ & $\mathbf{P t}^{4+}$ & $\mathbf{R h}^{3+}$ & $\mathrm{Ir}^{4+}$ & $R \mathbf{u}^{4+}$ & $\mathrm{Os}^{4+}$ \\
\hline & 25 & $\begin{array}{c}0.2-6 \mathrm{M} \\
5 \mathrm{~min}\end{array}$ & - & - & - & - & - \\
\hline TDTS & 95 & $\begin{array}{c}0.5-4 \mathrm{M} \\
5 \mathrm{~min}\end{array}$ & $\begin{array}{c}0.5-4 \mathrm{M} \\
10 \mathrm{~min}\end{array}$ & $\begin{array}{c}0.5-4 \mathrm{M} \\
5 \mathrm{~min} \\
\mathrm{SnCl}_{2}\end{array}$ & $\begin{array}{c}0.5-4 \mathrm{M} \\
30 \mathrm{~min} \\
\mathrm{SnCl}_{2}\end{array}$ & $\begin{array}{c}0.5-2 \mathrm{M} \\
40 \mathrm{~min} \\
\mathrm{SnCl}_{2}\end{array}$ & $\begin{array}{c}1-4 \mathrm{M} \\
60 \mathrm{~min} \\
\mathrm{SnCl}_{2}\end{array}$ \\
\hline & 25 & $\begin{array}{c}0.5-4 \mathrm{M} \\
5 \mathrm{~min}\end{array}$ & - & - & - & - & - \\
\hline MPhS & 95 & $\begin{array}{c}0.5-4 \mathrm{M} \\
5 \mathrm{~min}\end{array}$ & $\begin{array}{c}0.5-4 \mathrm{M} \\
5 \mathrm{~min} \\
\mathrm{SnCl}_{2}\end{array}$ & $\begin{array}{c}0.5-4 \mathrm{M} \\
5 \mathrm{~min} \\
\mathrm{SnCl}_{2}\end{array}$ & - & $\begin{array}{c}0.5-4 \mathrm{M} \\
10 \mathrm{~min} \\
\mathrm{SnCl}_{2}\end{array}$ & - \\
\hline ABTS & 25 & $\begin{array}{c}- \\
0.5-4 \mathrm{M} \\
5 \mathrm{~min} \\
\mathrm{SnCl}_{2}\end{array}$ & $\begin{array}{c}- \\
0.5-4 \mathrm{M} \\
5 \mathrm{~min} \\
\mathrm{SnCl}_{2}\end{array}$ & $\begin{array}{c}- \\
0.5-4 \mathrm{M} \\
15 \mathrm{~min} \\
\mathrm{SnCl}_{2}\end{array}$ & - & - & - \\
\hline
\end{tabular}

At room temperature, $\mathrm{Pt}^{4+}$ was extracted only by adsorbents containing thionic sulfur (ATUS, DTCS). At $95{ }^{\circ} \mathrm{C}, \mathrm{Pt}^{4+}$ was quantitatively recovered by all adsorbents, with the exception of DSS. A long phase contact time up to $30 \mathrm{~min}$ was required to attain the adsorption equilibrium when using MPhS and ABTS adsorbents. The ABTS adsorbent, the sulfur atom of which is in the heterocycle, is the least effective for the extraction of precious metal ions.

For the labilization of kinetically inert chlorocomplexes of platinum metals, tin(II) chloride was used as a labilizing agent. During the interaction of $\mathrm{Rh}^{3+}, \mathrm{Ir}^{4+}, \mathrm{Ru}^{4+}, \mathrm{Os}^{4+}$, as well as $\mathrm{Pd}^{2+}$ and $\mathrm{Pt}^{4+}$ with tin (II) chloride in solutions of hydrochloric acid, chloride-tin chloride complexes of various composition were formed, in which the central ion can be in various oxidation states, including the zero-valent state. The composition of the complexes depends on the concentration of acid and tin(II) chloride. The ligands $\mathrm{SnCl}_{3}{ }^{-}$have a strong trans-effect, which determines the kinetic lability of tinchloride complexes of precious metals in ligand substitution reactions. Thus, the addition of $\mathrm{SnCl}_{2}$ led to a decrease in the time of the attainment of the adsorption equilibrium during the extraction of $\mathrm{Pd}^{2+}$ and $\mathrm{Pt}^{4+}$ with MPhS and ABTS adsorbents for 5 min.

For the quantitative extraction of kinetically inert chloro complexes of platinum metals $\left(\mathrm{Rh}^{3+}, \mathrm{Ir}^{4+}, \mathrm{Ru}^{4+}, \mathrm{Os}^{4+}\right)$ from hydrochloric acid solutions using the proposed adsorbents, it was necessary to increase the temperature to $95{ }^{\circ} \mathrm{C}$ and /or add a labilizing agent- - tin(II) chloride (Table 2).

Without the addition of a labilizing agent, $\mathrm{Rh}^{3+}$ was quantitatively extracted from hydrochloric acid solutions at $95{ }^{\circ} \mathrm{C}$ with ATUS, MPS, DSS adsorbents; time of attainment of adsorption equilibrium was $20 \mathrm{~min}$ or less. The addition of tin(II) chloride made it possible to achieve a quantitative extraction of $\mathrm{Rh}^{3+}$ also with DTCS, TDTS, MPhS and ABTS adsorbents.

The quantitative extraction of $\mathrm{Ir}^{4+}$ with ATUS, DTKS, MPS, DSS adsorbents was observed at $95{ }^{\circ} \mathrm{C}$. For the quantitative extraction of $\mathrm{Ir}^{4+}$ by the TDTS adsorbent, it was necessary to add a labilizing agent.

ATUS, MPS, DSS adsorbents extracted $\mathrm{Ru}^{4+}$ from hydrochloric acid solutions at $95{ }^{\circ} \mathrm{C}$ without the addition of $\mathrm{SnCl}_{2}$. The quantitative extraction of $\mathrm{Ru}^{4+}$ with DTCS, TDTS, MPhS adsorbents and Os ${ }^{4+}$ with ATUS, DTCS, MPS, DSS, TDTS adsorbents was observed at $95^{\circ} \mathrm{C}$ and after adding a labilizing agent; the time of attainment of adsorption equilibrium was 30-60 min.

The quantitative extraction of $\mathrm{Ir}^{4+}, \mathrm{Ru}^{4+}, \mathrm{Os}^{4+}$ with the ABTS adsorbent was not achieved upon heating in the presence of $\mathrm{SnCl}_{2}$ even at a phase contact time of $60 \mathrm{~min}$.

A comparison of the extraction of $\mathrm{Ag}^{+}, \mathrm{Au}^{3+}$, and platinum group metals by silicas chemically modified with various sulfur-containing groups from $2 \mathrm{M} \mathrm{HCl}$ at room temper- 
ature is shown in Figure 1. Since solutions with a concentration of hydrochloric acid of $2 \mathrm{M}$ in most cases are final after digestion of natural and industrial samples; in these solutions precious metals are represented by chloride complexes of $\mathrm{Ag}^{+}, \mathrm{Au}^{3+}, \mathrm{Pd}^{2+}, \mathrm{Pt}^{4+}, \mathrm{Rh}^{3+}, \mathrm{Ir}^{4+}$, $\mathrm{Ru}^{4+}, \mathrm{Os}^{4+}$.

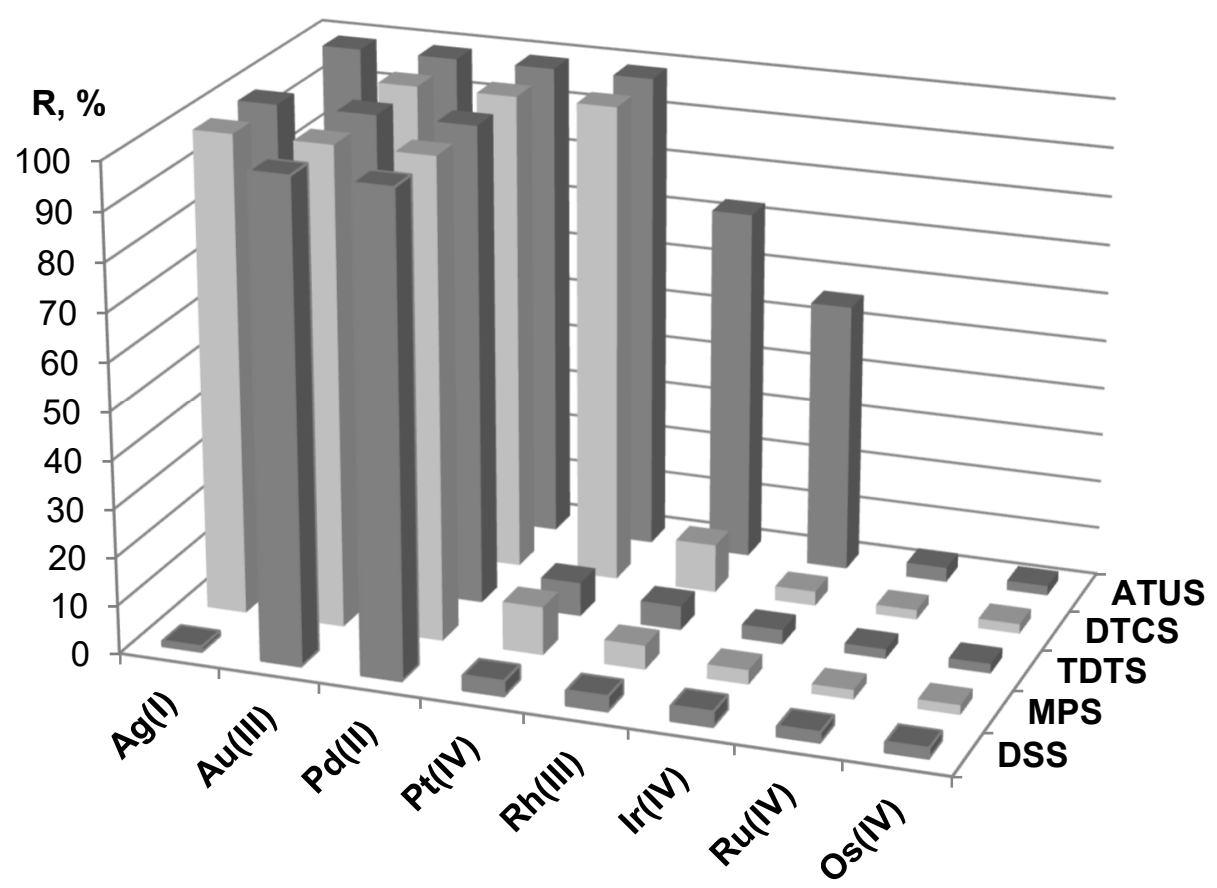

Figure 1. Extraction of platinum group metals, $\mathrm{Ag}^{+}$and $\mathrm{Au}^{3+}$ from $2 \mathrm{M} \mathrm{HCl}$ using silicas chemically modified with sulfur-containing groups at room temperature $\left(C_{M e}=5 \mu \mathrm{g} \cdot \mathrm{mL}^{-1}, 25^{\circ} \mathrm{C}, 0.1 \mathrm{~g}\right.$ of adsorbent, phase contact time of $10 \mathrm{~min}$ ).

As can be seen from Figure 1, CMS with thiourea derivative, along with the quantitative extraction of $\mathrm{Ag}^{+}, \mathrm{Au}^{3+}, \mathrm{Pd}^{2+}$ and $\mathrm{Pt}^{4+}$, also partially extracted $\mathrm{Rh}^{3+}$ and $\mathrm{Ir}^{4+}$; their extraction was $75 \%$ and $60 \%$, respectively. When using adsorbents containing thiol sulfur in the functional group (MPS, TDTS, MPhS), a similar dependence was observed: quantitative extraction from hydrochloric acid solutions at room temperature was attained only for $\mathrm{Ag}^{+}, \mathrm{Au}^{3+}, \mathrm{Pd}^{2+}$, and there was practically no adsorption of $\mathrm{Pt}^{4+}$ and other kinetically inert platinum group metals $\left(\mathrm{Rh}^{3+}, \mathrm{Ir}^{4+}, \mathrm{Ru}^{4+}, \mathrm{Os}^{4+}\right)$. The adsorbent with dipropyldisulfide groups exhibited the best selectivity and extracted only $\mathrm{Pd}^{2+}$ and $\mathrm{Au}^{3+}$ from $2 \mathrm{M} \mathrm{HCl}$. Thus, the selectivity of adsorbents for intragroup separation of platinum group metals increased from adsorbents with functional groups containing thionic sulfur to adsorbents with groups containing thiol sulfur, and further to adsorbents with disulfide groups.

When passing from $4 \mathrm{M} \mathrm{HCl}$ to more dilute solutions of hydrochloric acid $(0.5-2 \mathrm{M})$, chloride complexes of precious metals are aquated with the formation of aquachloride complexes of various composition and charge. The quantitative extraction of precious metals in a wide range of hydrochloric acid concentrations $(0.5-4 \mathrm{M})$ indicates the absence of a noticeable effect of the composition of the inner coordination sphere of precious metal complexes on their interaction with sulfur-containing groups of adsorbents. The main effect on the extraction of precious metals was exerted by the nature of the sulfurcontaining functional group, covalently attached to the silica surface, and the nature of the precious metal.

Thus, the use of CMS with sulfur-containing groups allows us to solve the main problems in the field of analytical chemistry of precious metals:

- Separation of a group of precious metals $\left(\mathrm{Au}^{3+}, \mathrm{Pd}^{2+}, \mathrm{Pt}^{2+}, \mathrm{Pt}^{4+}, \mathrm{Rh}^{3+}, \mathrm{Ir}^{4+}, \mathrm{Ru}^{4+}\right.$, and $\mathrm{Os}^{4+}$ ) using ATUS, MPS, MPhS, and DTCS adsorbents at $95{ }^{\circ} \mathrm{C}$ in the presence of tin(II) chloride from the prevailing amounts of related elements. 
- Separation of platinum metal ions that are kinetically labile in the reactions of ligand substitution from kinetically inert ones (for example, the ATUS and DTCS adsorbents at room temperature made possible the quantitative extraction of $\mathrm{Ag}^{+}, \mathrm{Au}^{3+}, \mathrm{Pd}^{2+}$, and $\mathrm{Pt}^{4+}$, while the TDTS and MPS adsorbents-extraction of $\mathrm{Ag}^{+}, \mathrm{Au}^{3+}, \mathrm{Pd}^{2+}$ separated them from $\mathrm{Rh}^{3+}, \mathrm{Ir}^{4+}, \mathrm{Ru}^{4+}$ and $\mathrm{Os}^{4+}$; the DPSS adsorbent made it possible to selectively isolate only $\mathrm{Au}^{3+}$ and $\mathrm{Pd}^{2+}$ from hydrochloric acid solutions).

- Separation of platinum metals with similar chemical properties (for example, the use of TDTS, MPS, and DPSS adsorbents made it possible to separate $\mathrm{Pd}^{2+}$ from $\mathrm{Pt}^{4+}$ ).

\subsection{Determination of Platinum Group Metals, $\mathrm{Ag}^{+}$, and $\mathrm{Au}{ }^{3+}$ in Geological Samples and Their Processing Products}

The adsorption of precious metals in the column mode allows them to be preconcentrated from large volumes of solutions and to achieve a greater extraction of elements in comparison with adsorption in the batch mode. By means of SPE of precious metals from acidic solutions, it is possible to effectively separate them from the prevailing amounts of non-ferrous and other accompanying metals, which is important in the analysis of geological materials and the products of their processing.

In addition, it is possible to effectively separate kinetically labile chloro complexes of platinum metals from kinetically inert ones in a dynamic mode, since the latter were not retained by the proposed adsorbents at room temperature.

The glatinum group metals, $\mathrm{Ag}^{+}$and $\mathrm{Au}^{3+}$, were determined (including to check the correctness of the results obtained) in certified reference materials of sulfide coppernickel and gold-bearing ores and products of their processing (concentrates, tailings, matte, feinstein, blister and cathode copper). The approximate content of accompanying nonferrous and other metals in the samples is given in Table S4.

For the simultaneous determination of platinum group metals, gold and silver, it is advisable to use multielement methods of analysis-ICP-OES and ICP-MS. To determine one or two precious metals, for example, gold, silver, palladium or platinum, FAAS or GFAAS (depending on the concentration of the element being determined) can be used.

For the solid-phase extraction of $\mathrm{Ag}^{+}, \mathrm{Au}^{3+}, \mathrm{Pd}^{2+}$ and $\mathrm{Pt}^{4+}$ and their separation from the ions of non-ferrous and other accompanying metals, as well as kinetically inert platinum metals in a dynamic mode using a single-column method (Figure 2a) an ATUS adsorbent was used for the preconcentration of $\mathrm{Ag}^{+}, \mathrm{Au}^{3+}, \mathrm{Pd}^{2+}$ - TDTS adsorbent and for preconcentration of $\mathrm{Au}^{3+}, \mathrm{Pd}^{2+}-\mathrm{MPS}$ adsorbent.
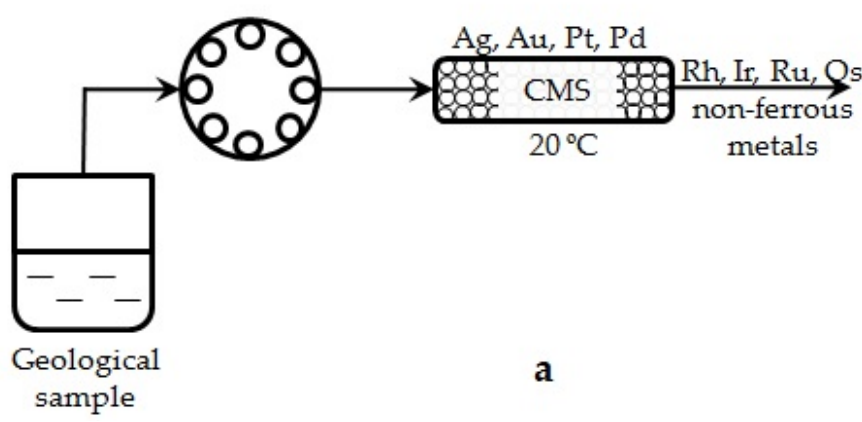

Figure 2. Single-column system for SPE of kinetically labile complexes of platinum group metals (a) and for simultaneous SPE of all precious metals (b).

Although the degree of $\mathrm{Cu}^{2+}$ extraction from $1 \mathrm{M} \mathrm{HCl}$ by DTCS and MPS adsorbents was $40 \%$ and $80 \%$, respectively (Figure S1), it did not interfere with the solid-phase extraction of precious metals. Thus, when solutions containing $\mathrm{Pd}^{2+}$ and $\mathrm{Cu}^{2+}$ were passed through the column, the upper zone of the adsorbent was colored brown, corresponding to palladium complexes with sulfur-containing groups attached to the silica surface, and the entire surface of the adsorbent in the column became yellow-green, corresponding to 
adsorbed copper. After passing 1-2 M HCl, the yellow-green color of the adsorbent disappeared as a result of copper desorption, while the zone corresponding to the palladium complex remained unchanged. This confirms the lower stability of copper complexes with sulfur-containing groups in acidic media. When dilute solutions of hydrochloric acid were passed through the column, adsorbed bismuth and lead ions were also removed from the surface, which were partially adsorbed from slightly acidic solutions.

To determine silver, gold, palladium and platinum in a single-column mode, the solution after decomposition of geological sample $(50 \mathrm{~mL})$ was passed through a glass column containing $0.1 \mathrm{~g}$ of adsorbent, at a flow rate of $1 \mathrm{~mL} \cdot \mathrm{min}^{-1}$, at room temperature. To remove the adsorbed ions of the accompanying elements, $20 \mathrm{~mL}$ of $2 \mathrm{M} \mathrm{HCl}$ was passed through the column. Desorption of kinetically labile precious metals was carried out at room temperature by passing of $10 \mathrm{~mL}$ of a $10 \% w / v$ thiourea solution in $1 \mathrm{M} \mathrm{HCl}$ through the column at a flow rate of $1 \mathrm{~mL} \cdot \mathrm{min}^{-1}$.

FAAS and GFAAS were used for determination of silver, gold, palladium, and platinum in eluates. Calibration graphs were constructed against standards prepared using the eluent (thiourea solution) as matrix and blank solution. The results of silver, gold, palladium and platinum determination are given in Table 3.

Table 3. Results of determination of precious metals in geological samples and products of their processing using SPE-FAAS and SPE-GFAAS methods ( $\mathrm{n}=5, \mathrm{P}=0.95)$.

\begin{tabular}{|c|c|c|c|c|c|c|}
\hline \multirow{2}{*}{ Adsorbent } & \multirow{2}{*}{ Sample } & \multicolumn{4}{|c|}{ Found, $g \cdot t^{-1}\left(\right.$ Certified, $\left.g \cdot t^{-1}\right)$} & \multirow{2}{*}{ Method } \\
\hline & & $\mathrm{Ag}$ & $\mathrm{Au}$ & Pd & $\mathbf{P t}$ & \\
\hline \multirow{4}{*}{ ATUS } & $\begin{array}{l}\text { Sulfide copper-nickel ore } \\
(\mathrm{VT}-1 \text { GSO * no. 929-86) }\end{array}$ & $\begin{array}{c}2.8 \pm 0.3 \\
(2.6 \pm 0.4)\end{array}$ & $\begin{array}{c}0.25 \pm 0.03 \\
(0.26 \pm 0.04)\end{array}$ & $\begin{array}{c}6.3 \pm 0.5 \\
(6.40 \pm 0.45)\end{array}$ & $\begin{array}{c}2.6 \pm 0.2 \\
(2.55 \pm 0.34)\end{array}$ & \multirow{4}{*}{ FAAS } \\
\hline & $\begin{array}{l}\text { Matte of ore-thermal smelting } \\
\text { (ShT-1 GSO no. 2432-83) }\end{array}$ & $\begin{array}{c}41.6 \pm 0.8 \\
(41.45 \pm 9.46)\end{array}$ & $\begin{array}{c}1.66 \pm 0.06 \\
(1.62 \pm 0.16)\end{array}$ & $\begin{array}{c}51.4 \pm 0.8 \\
(51.5 \pm 2.6)\end{array}$ & $\begin{array}{c}16 \pm 1 \\
(16.60 \pm 1.56)\end{array}$ & \\
\hline & $\begin{array}{c}\text { Copper alloys with precious metals } \\
\text { GSO no. } 933-76 \\
\text { GSO no. } 934-76 \\
\text { GSO no. } 935-76\end{array}$ & $\begin{array}{c}176 \pm 2 \\
(180 \pm 10) \\
-* * \\
- \\
28 \pm 1 \\
(30 \pm 6)\end{array}$ & $\begin{array}{c}29.7 \pm 0.06 \\
(29 \pm 1) \\
9.6 \pm 0.8 \\
(10 \pm 1) \\
4.7 \pm 0.7 \\
(5 \pm 1)\end{array}$ & $\begin{array}{c}305 \pm 4 \\
(310 \pm 10) \\
97 \pm 3 \\
(100 \pm 10) \\
50.5 \pm 0.5 \\
(49 \pm 2)\end{array}$ & $\begin{array}{c}97 \pm 3 \\
(100 \pm 10) \\
29.6 \pm 08 \\
(30 \pm 1) \\
13 \pm 1 \\
(15 \pm 2)\end{array}$ & \\
\hline & $\begin{array}{l}\text { Copper ore of the Chineysky } \\
\text { deposit (Chita Oblast, Russia) } \\
\text { Sample } 12 \\
\text { Sample } 13\end{array}$ & $\begin{array}{l}14.2 \pm 0.1 \\
(14.0 \pm 0.3) \\
21.0 \pm 0.1 \\
(21.1 \pm 0.3)\end{array}$ & $\begin{array}{c}4.7 \pm 0.2 \\
(4.9 \pm 0.3) \\
3.9 \pm 0.1 \\
(3.9 \pm 0.2)\end{array}$ & $\begin{array}{c}4.0 \pm 0.1 \\
(4.1 \pm 0.2) \\
6.3 \pm 0.3 \\
(6.4 \pm 0.5)\end{array}$ & $\begin{aligned} 5.0 & \pm 0.5 \\
(5.4 & \pm 0.6) \\
& -\end{aligned}$ & \\
\hline \multirow{6}{*}{ MPS } & Blister copper & $\begin{array}{c}200 \pm 5 \\
(213 \pm 3)\end{array}$ & $\begin{array}{c}3.0 \pm 0.1 \\
(2.96 \pm 0.06)\end{array}$ & $\begin{array}{c}2.5 \pm 0.1 \\
(2.35 \pm 0.05)\end{array}$ & n.d. ${ }^{* * *}$ & \multirow{4}{*}{ FAAS } \\
\hline & Cathode copper & $\begin{array}{l}13.8 \pm 0.8 \\
(14.0 \pm 0.5)\end{array}$ & $\begin{array}{c}2.4 \pm 0.2 \\
(2.2 \pm 0.2)\end{array}$ & - & n.d. & \\
\hline & $\begin{array}{l}\text { Copper concentrate (KM-1 GSO no. } \\
\text { 1701-86) }\end{array}$ & $\begin{array}{c}70 \pm 1 \\
(-)\end{array}$ & $\begin{array}{c}3.5 \pm 0.4 \\
(3.8 \pm 0.3)\end{array}$ & $\begin{array}{c}37.8 \pm 0.8 \\
(37.6 \pm 4.2)\end{array}$ & n.d. & \\
\hline & $\begin{array}{l}\text { Gold-bearing flotation concentrate } \\
\text { SOP } * * * * \\
\text { ZSK-3-99 }\end{array}$ & $\begin{array}{c}1.85 \pm 0.09 \\
(1.92 \pm 0.38)\end{array}$ & $\begin{array}{c}105 \pm 4 \\
(103 \pm 6)\end{array}$ & - & n.d. & \\
\hline & $\begin{array}{c}\text { Gold ore } \\
\text { SOP ZSR-1-99 }\end{array}$ & $\begin{array}{c}0.08 \pm 0.02 \\
(0.09 \pm 0.05)\end{array}$ & $\begin{array}{c}3.4 \pm 0.3 \\
(3.3 \pm 0.3)\end{array}$ & - & - & \multirow{2}{*}{ GFAAS } \\
\hline & $\begin{array}{c}\text { Concentration tailing (ChO-1 GSO } \\
\text { no. 1703-86 }\end{array}$ & $\begin{array}{c}0.50 \pm 0.08 \\
(0.58 \pm 0.07)\end{array}$ & $\begin{array}{c}0.10 \pm 0.01 \\
(0.07 \pm 0.01)\end{array}$ & $\begin{array}{c}0.82 \pm 0.06 \\
(0.84 \pm 0.17)\end{array}$ & n.d. & \\
\hline \multirow{3}{*}{ DSS } & $\begin{array}{l}\text { Copper concentrate (KM-1 GSO no. } \\
1701-86)\end{array}$ & n.d. & $\begin{array}{c}3.7 \pm 0.3 \\
(3.8 \pm 0.3)\end{array}$ & $\begin{array}{c}37.2 \pm 0.5 \\
(37.6 \pm 4.2)\end{array}$ & n.d. & \multirow{2}{*}{ FAAS } \\
\hline & $\begin{array}{l}\text { Sulfide copper-nickel ore } \\
\text { (VT-1 GSO no. 929-86) }\end{array}$ & n.d. & $\begin{array}{c}0.29 \pm 0.04 \\
(0.26 \pm 0.04)\end{array}$ & $\begin{array}{c}6.3 \pm 0.3 \\
(6.40 \pm 0.45)\end{array}$ & n.d. & \\
\hline & $\begin{array}{c}\text { Concentration tailing (ChO-1 GSO } \\
\text { no. 1703-86 }\end{array}$ & n.d. & $\begin{array}{c}0.07 \pm 0.01 \\
(0.07 \pm 0.01)\end{array}$ & $\begin{array}{c}0.81 \pm 0.07 \\
(0.84 \pm 0.17)\end{array}$ & n.d. & GFAAS \\
\hline
\end{tabular}

*GSO—national standard sample; ${ }^{* *}$ "_" —not certified; ${ }^{* * *}$ n.d.—not detected; ${ }^{* * * *}$ SOP—factory standard sample. 
The single-column mode was used for the simultaneous preconcentration of all precious metals using ATUS and DTCS adsorbents (Figure $2 b$ ). Then, $1.0 \mathrm{~mL}$ of $0.025 \mathrm{M} \mathrm{SnCl}_{2}$ was added to the solution prior to SPE, and the resulting solution was passed through the thermostated glass column at $95^{\circ} \mathrm{C}$ filled with $0.1 \mathrm{~g}$ of the adsorbent with the flow rate of $1.0 \mathrm{~mL} \cdot \mathrm{min}^{-1}$. The column was rinsed with $20.0 \mathrm{~mL}$ of $2 \mathrm{M} \mathrm{HCl}$ to remove the adsorbed ions of accompanying elements. The desorption of the precious metals was carried out at $95^{\circ} \mathrm{C}$ by passing through the column $10.0 \mathrm{~mL}$ of a $10 \% w / v$ solution of thiourea in $1 \mathrm{M}$ $\mathrm{HCl}$ at a solution flow rate of $1 \mathrm{~mL} \cdot \mathrm{min}^{-1}$. The content of precious metals in the eluates was determined by ICP-OES and ICP-MS. Calibration graphs were constructed against standards prepared using the eluent (thiourea solution) as matrix and blank solution. The results of the determination of the precious metals are represented in Table 4.

Table 4. Results of SPE-ICP-OES and SPE-ICP-MS determination of Au and platinum group metals in ore samples and their processing products using silicas chemically modified with sulfur-containing groups $(n=5, P=0.95)$.

\begin{tabular}{|c|c|c|c|c|c|c|c|c|c|}
\hline \multirow{2}{*}{ Adsorbent } & \multirow{2}{*}{ Sample } & \multicolumn{8}{|c|}{ Found, $g \cdot t^{-1}\left(\right.$ Certified, $\left.g \cdot t^{-1}\right)$} \\
\hline & & Ag & $\mathrm{Au}$ & Pd & $\mathbf{P t}$ & Rh & Ir & $\mathbf{R u}$ & Os \\
\hline \multirow{2}{*}{ ATUS } & $\begin{array}{c}\text { Nickel } \\
\text { concentrate } \\
(\mathrm{KN}-1 \text { GSO } \\
\text { no. 1702-86) }\end{array}$ & $\begin{array}{c}24.3 \pm 0.6 \\
(23.4 \pm \\
2.2)\end{array}$ & $\begin{array}{c}0.9 \pm 0.1^{*} \\
(0.84 \pm 0.09)\end{array}$ & $\begin{array}{c}29.8 \pm 0.3 \\
(30.0 \pm 2.2)\end{array}$ & $\begin{array}{c}8.3 \pm 0.3 \\
(8.6 \pm 0.3)\end{array}$ & $\begin{array}{l}0.95 \pm 0.07 * \\
(0.98 \pm 0.09)\end{array}$ & $\begin{array}{l}0.10 \pm 0.02 * \\
(0.11 \pm 0.01)\end{array}$ & $\begin{array}{c}0.30 \pm 0.05^{*} \\
(0.34 \pm 0.06)\end{array}$ & $\begin{array}{l}0.06 \pm 0.01 * \\
(0.06 \pm 0.01)\end{array}$ \\
\hline & $\begin{array}{l}\text { Matte of } \\
\text { ore-thermal } \\
\text { smelting } \\
\text { (ShT-1 GSO } \\
\text { no. 2432-83) }\end{array}$ & $\begin{array}{l}41.6 \pm 0.7 \\
(41.45 \pm \\
9.46)\end{array}$ & $\begin{array}{c}1.7 \pm 0.1 \\
(1.62 \pm 0.16)\end{array}$ & $\begin{array}{c}51.4 \pm 0.5 \\
(51.5 \pm 2.60)\end{array}$ & $\begin{array}{c}16.3 \pm 0.4 \\
(16.60 \pm \\
1.56)\end{array}$ & $\begin{array}{c}3.7 \pm 0.1 \\
(3.72 \pm 0.50)\end{array}$ & $\begin{array}{l}0.39 \pm 0.06^{*} \\
(0.43 \pm 0.06)\end{array}$ & $\begin{array}{c}1.1 \pm 0.1 * \\
(1.16 \pm 0.15)\end{array}$ & $\begin{array}{l}0.14 \pm 0.06^{*} \\
(0.17 \pm 0.08)\end{array}$ \\
\hline \multirow{2}{*}{ TDTS } & $\begin{array}{c}\text { Sulfide } \\
\text { copper- } \\
\text { nickel ore } \\
\text { (VT-1 GSO } \\
\text { no. 929-86) }\end{array}$ & $\begin{array}{c}2.8 \pm 0.3 \\
(2.6 \pm 0.4)\end{array}$ & $\begin{array}{l}0.24 \pm 0.05^{*} \\
(0.26 \pm 0.04)\end{array}$ & $\begin{array}{c}6.3 \pm 0.3 \\
(6.4 \pm 0.5)\end{array}$ & $\begin{array}{c}2.5 \pm 0.2 \\
(2.55 \pm 0.34)\end{array}$ & $\begin{array}{l}0.31 \pm 0.03^{*} \\
(0.33 \pm 0.05)\end{array}$ & $\begin{array}{c}0.04 \pm 0.01 * \\
(0.041 \pm 0.005)\end{array}$ & $\begin{array}{l}0.09 \pm 0.01 \\
(0.10 \pm 0.01)\end{array}$ & $\begin{array}{l}0.02 \pm 0.01 * \\
(0.02 \pm 0.01)\end{array}$ \\
\hline & $\begin{array}{l}\text { Matte of } \\
\text { ore-thermal } \\
\text { smelting } \\
\text { (ShT-1 GSO } \\
\text { no. 2432-83) }\end{array}$ & $\begin{array}{l}41.3 \pm 0.6 \\
(41.45 \pm \\
9.46)\end{array}$ & $\begin{array}{c}1.68 \pm 0.07 \\
(1.62 \pm 0.16)\end{array}$ & $\begin{array}{c}50.8 \pm 0.4 \\
(51.5 \pm 2.60)\end{array}$ & $\begin{array}{c}16.9 \pm 0.5 \\
(16.60 \pm \\
1.56)\end{array}$ & $\begin{array}{c}3.62 \pm 0.08 \\
(3.72 \pm 0.50)\end{array}$ & $\begin{array}{l}0.40 \pm 0.05^{*} \\
(0.43 \pm 0.06)\end{array}$ & $\begin{array}{c}1.2 \pm 0.1^{*} \\
(1.16 \pm 0.15)\end{array}$ & $\begin{array}{l}0.16 \pm 0.06^{*} \\
(0.17 \pm 0.08)\end{array}$ \\
\hline \multirow[b]{2}{*}{ MPhS } & $\begin{array}{c}\text { Nickel } \\
\text { concentrate } \\
(\mathrm{KN}-1 \text { GSO } \\
\text { no. } 1702-86)\end{array}$ & $\begin{array}{c}24.1 \pm 0.8 \\
(23.4 \pm \\
2.2)\end{array}$ & $\begin{array}{c}0.8 \pm 0.1^{*} \\
(0.84 \pm 0.09)\end{array}$ & $\begin{array}{c}30.2 \pm 0.3 \\
(30.0 \pm 2.2)\end{array}$ & $\begin{array}{c}8.5 \pm 0.2 \\
(8.6 \pm 0.3)\end{array}$ & $\begin{array}{c}1.0 \pm 0.1^{*} \\
(0.98 \pm 0.09)\end{array}$ & $\begin{array}{l}0.12 \pm 0.02 * \\
(0.11 \pm 0.01)\end{array}$ & $\begin{array}{l}0.31 \pm 0.05^{*} \\
(0.34 \pm 0.06)\end{array}$ & $\begin{array}{l}0.05 \pm 0.01 * \\
(0.06 \pm 0.01)\end{array}$ \\
\hline & $\begin{array}{c}\text { Copper- } \\
\text { nickel } \\
\text { feinstein } \\
\text { (FShT-42 } \\
\text { GSO } \\
9315-2009)\end{array}$ & $\begin{array}{c}105 \pm 3 \\
(107 \pm 4)\end{array}$ & $\begin{array}{c}2.56 \pm 0.07 \\
(2.55 \pm 0.11)\end{array}$ & $\begin{array}{c}131 \pm 1 \\
(130 \pm 2)\end{array}$ & $\begin{array}{c}23.8 \pm 0.3 \\
(24.0 \pm 0.6)\end{array}$ & $\begin{array}{c}5.3 \pm 0.2 \\
(5.45 \pm 0.20)\end{array}$ & $\begin{array}{c}0.58 \pm 0.03 * \\
(0.6 \pm 0.03)\end{array}$ & $\begin{array}{c}1.7 \pm 0.1^{*} \\
(1.70 \pm 0.09)\end{array}$ & $\begin{array}{l}0.21 \pm 0.02 * \\
(0.23 \pm 0.02)\end{array}$ \\
\hline \multirow{2}{*}{ DTCS } & $\begin{array}{c}\text { Concentration } \\
\text { tailing } \\
(\mathrm{ChO}-1 \mathrm{GSO} \\
\text { no. 1703-86) }\end{array}$ & - & $\begin{array}{l}0.10 \pm 0.01 * \\
(0.07 \pm 0.01)\end{array}$ & $\begin{array}{l}0.82 \pm 0.06 * \\
(0.84 \pm 0.17)\end{array}$ & $\begin{array}{c}0.5 \pm 0.1 * \\
(0.43 \pm 0.09)\end{array}$ & $\begin{array}{c}0.1 \pm 0.01 * \\
(0.096 \pm \\
0.013)\end{array}$ & $\begin{array}{l}0.09 \pm 0.01^{*} \\
(0.10 \pm 0.01)\end{array}$ & $\begin{array}{l}0.025 \pm 0.009 * \\
(0.029 \pm 0.013)\end{array}$ & $\begin{array}{l}0.010 \pm 0.006^{*} \\
(0.011 \pm 0.004)\end{array}$ \\
\hline & $\begin{array}{c}\text { Copper } \\
\text { concentrate } \\
\text { (KM-1 GSO } \\
\text { no. } 1701-86)\end{array}$ & - & $\begin{array}{c}3.7 \pm 0.3 \\
(3.8 \pm 0.3)\end{array}$ & $\begin{array}{c}37.2 \pm 0.5 \\
(37.6 \pm 4.2)\end{array}$ & $\begin{array}{c}8.5 \pm 0.3 \\
(8.6 \pm 0.4)\end{array}$ & $\begin{array}{l}0.25 \pm 0.02 \\
(0.27 \pm 0.02)\end{array}$ & $\begin{array}{l}0.050 \pm 0.005^{*} \\
(0.052 \pm 0.004)\end{array}$ & $\begin{array}{l}0.11 \pm 0.02 * \\
(0.12 \pm 0.01)\end{array}$ & $\begin{array}{l}0.020 \pm 0.003 * \\
(0.022 \pm 0.002)\end{array}$ \\
\hline
\end{tabular}

* SPE-ICP-MS.

As can be seen from Tables 3 and 4, the results obtained are characterized by high accuracy and reproducibility.

The two-column procedure (Figure 3) was used for sequential separation and preconcentration of kinetically labile $\left(\mathrm{Au}^{3+}, \mathrm{Pd}^{2+}, \mathrm{Pt}^{2+}, \mathrm{Pt}^{4+}\right)$ and kinetically inert $\left(\mathrm{Rh}^{3+}, \mathrm{Ir}^{4+}\right.$, $\mathrm{Ru}^{4+}$ and $\mathrm{Os}^{4+}$ ) precious metals using DTCS adsorbent. For this, $50.0 \mathrm{~mL}$ of a solution containing precious metal ions in $2 \mathrm{M} \mathrm{HCl}$ was passed through a system of two columns with a solution flow rate of $1.0 \mathrm{~mL} \cdot \mathrm{min}^{-1}$. $\mathrm{SnCl}_{2}$ solution was added in the stream after the first column (1) at $20^{\circ} \mathrm{C}$ by means of tap (2) with the flow rate of $1.0 \mathrm{~mL} \cdot \mathrm{min}^{-1}$. Then, the solution was passed through the second thermostated column (3) at $95^{\circ} \mathrm{C}$. Then, $20.0 \mathrm{~mL}$ of $2.0 \mathrm{M} \mathrm{HCl}$ was pumped through two-column system in order to remove retained nonferrous metals and $\mathrm{SnCl}_{2}$. The desorption of retained precious metals was carried out by passing of $10.0 \mathrm{~mL} 10 \%(w / v)$ thiourea solution in $1.0 \mathrm{M} \mathrm{HCl}$ through each column with 
the flow rate of $1.0 \mathrm{~mL} \cdot \mathrm{min}^{-1}$ : at $20{ }^{\circ} \mathrm{C}$ through the first column and $95{ }^{\circ} \mathrm{C}$ through the second one.

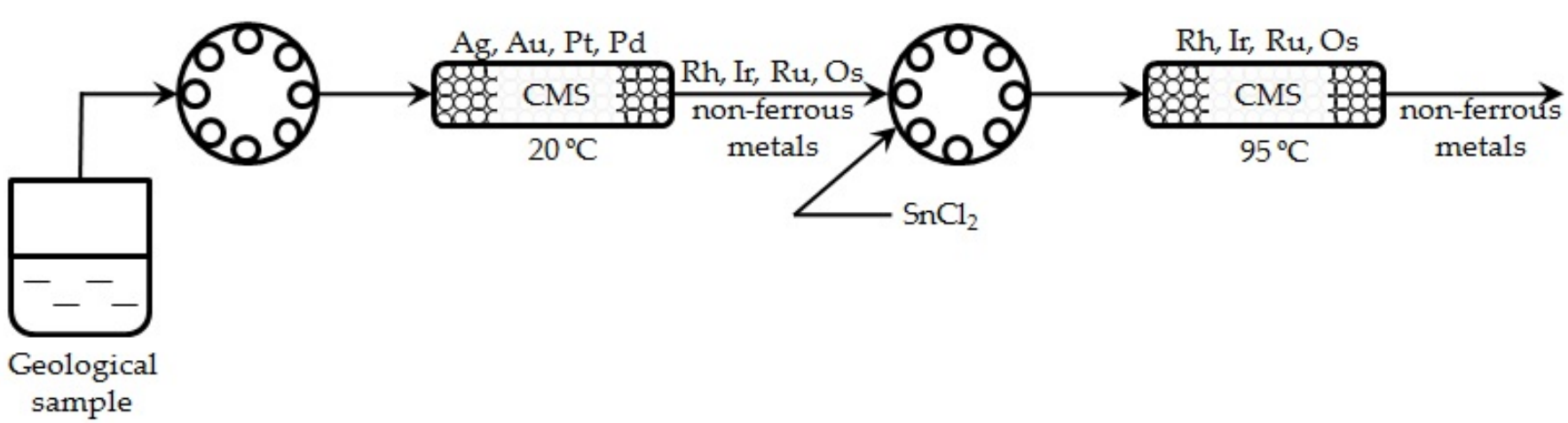

Figure 3. Two-column system for separation of kinetically labile precious metals from kinetically inert ones.

The results of the determination of precious metals in the tailings obtained by the single-column and two-column methods of preconcentration using DTCS adsorbent are identical (Table 4).

\section{Conclusions}

Silicas chemically modified with sulfur-containing groups quantitatively extracted precious metals (gold, silver, and platinum group metals) mainly from 0.5 to $4 \mathrm{M}$ solutions of hydrochloric acid and made it possible to efficiently separate them from the accompanying metals. The range of quantitative recovery depended on the nature of the functional group of the adsorbent and the nature of the extracted precious metal ion. Adsorbents with functional groups containing thionic sulfur made it possible to separate kinetically labile chloro complexes of precious metals $\left(\mathrm{Ag}^{+}, \mathrm{Au}^{3+}, \mathrm{Pd}^{2+}, \mathrm{Pt}^{4+}\right)$ in ligand substitution reactions from kinetically inert chloro complexes $\left(\mathrm{Rh}^{3+}, \mathrm{Ir}^{4+}, \mathrm{Ru}^{4+}, \mathrm{Os}^{4+}\right)$ at room temperature. Solid-phase extraction at $95^{\circ} \mathrm{C}$ in the presence of a labilizing agent $\left(\mathrm{SnCl}_{2}\right)$ made it possible to preconcentrate all precious metals simultaneously. The transition from adsorbents with functional groups containing thionic sulfur to adsorbents with groups containing thiol sulfur and then to disulfide groups leads to an increase in the selectivity of intragroup separation of precious metals. The hyphenated methods of SPE-FAAS, SPE-GFAAS, SPEICP-OES and SPE-ICP-MS determination of precious metals in geological materials and products of their processing using silicas with sulfur-containing functional groups were proposed. The analysis of certified reference materials for precious metals shown high accuracy and reproducibility of the results obtained.

Supplementary Materials: The following are available online at https:/ / www.mdpi.com/article / 10.3390/min11050481/s1, Table S1. ICP-OES operational conditions; Table S2. ICP-MS operational conditions; Table S3. FAAS and GFAAS operational conditions; Table S4. Average content of accompanying elements in analyzed samples; Figure S1. Extraction of $\mathrm{Bi}(\mathrm{III})$ (1); $\mathrm{Cu}(\mathrm{II})(2) ; \mathrm{Pb}(\mathrm{II})$ (3); Cd(II) (4); Zn(II) (5); Co(II) (6); Ni(II) (7), Fe(III) (8); Fe(II) (9) with MPS, DSS, DTCS, and TDTS adsorbents vs. $\mathrm{pH}\left(C_{\mathrm{Me}}=10 \mu \mathrm{g} \cdot \mathrm{mL}^{-1}, \mathrm{~V}=10 \mathrm{~mL}, 0.1 \mathrm{~g}\right.$ of adsorbent).

Author Contributions: Writing—original draft and project administration, V.L.; investigation, E.E.; formal analysis and data curation, E.B.; writing-review, editing and visualization, O.B.; validation, N.M.; methodology, A.T. All authors have read and agreed to the published version of the manuscript.

Funding: This research received no external funding.

Conflicts of Interest: The authors declare no conflict of interest. 


\section{References}

1. Mitra, A.; Sen, I.S.; Walkner, C.; Meisel, T.C. Simultaneous determination of platinum group elements and rhenium mass fractions in road dust samples using isotope dilution inductively coupled plasma-tandem mass spectrometry after cation exchange separation. Spectrochim. Acta Part B At. Spectrosc. 2021, 177, 106052. [CrossRef]

2. Ni, W.; Zhang, H.; Mao, X.; Liu, L.; Guo, X.; Xiao, F.; Gao, X. Simultaneous determination of ultra-trace Au, Pt, Pd, Ru, Rh, Os and Ir in geochemical samples by KED-ICP-MS combined with Sb-Cu fire assay and microwave digestion. Microchem. J. 2020, 158, 105197. [CrossRef]

3. Avarmaa, K.; O’Brien, H.; Klemettinen, L.; Taskinen, P. Precious metal recoveries in secondary copper smelting with high-alumina slags. J. Mater. Cycles Waste Manag. 2019, 22, 642-655. [CrossRef]

4. Hubicki, Z.; Wawrzkiewicz, M.; Wójcik, G.; Kolodynska, D.; Wolowicz, A. Ion Exchange Method for Removal and Separation of Noble Metal Ions. Ion Exch. Stud. Appl. 2015. [CrossRef]

5. Bannister, S.J.; Chang, Y.; Sternson, L.; Repta, A.J. Atomic absorption spectrophotometry of free circulating platinum species in plasma derived from cis-dichlorodiammineplatinum(II). Clin. Chem. 1978, 24, 877-880. [CrossRef]

6. Brajter, K.; Kleyny, K.; Vorbrodt, Z. Studies on optimization of conditions for separating rhodium and platinum by cation-exchange. Talanta 1980, 27, 433-435. [CrossRef]

7. Kononova, O.N.; Duba, E.V.; Shnaider, N.I.; Pozdnyakov, I.A. Ion exchange extraction of platinum(IV) and palladium(II) from hydrochloric acid solutions. Russ. J. Appl. Chem. 2017, 90, 1239-1245. [CrossRef]

8. Fujiwara, M.; Matsushita, T.; Kobayashi, T.; Yamashoji, Y.; Tanaka, M. Preparation of an anion-exchange resin with quaternary phosphonium chloride and its adsorption behaviour for noble metal ions. Anal. Chim. Acta 1993, 274, 293-297. [CrossRef]

9. Suzuki, T.; Fujii, Y.; Yan, W.; Mimura, H.; Koyama, S.-I.; Ozawa, M. Adsorption behavior of VII group elements on tertiary pyridine resin in hydrochloric acid solution. J. Radioanal. Nucl. Chem. 2009, 282, 641-644. [CrossRef]

10. Cyganowski, P.; Dzimitrowicz, A. A Mini-Review on Anion Exchange and Chelating Polymers for Applications in Hydrometallurgy, Environmental Protection, and Biomedicine. Polymers 2020, 12, 784. [CrossRef] [PubMed]

11. Hubicki, Z.; Wójcik, G. Studies of the Selective Removal of Micro-Quantities of Platinum(IV) Ions from Macro-Quantities of Model Solutions of Aluminium, Copper, Iron, Nickel and Zinc Chloride on Anion-Exchangers of Various Types. Adsorpt. Sci. Technol. 2006, 24, 559-569. [CrossRef]

12. Losev, V.N.; Buyko, O.V.; Borodina, E.V.; Samoilo, A.S.; Zhyzhaev, A.M.; Velichko, B.A. Biosorbents based on pine sawdust and malt sprouts for preconcentration and ICP-OES determination of nonferrous, heavy, and precious metals in the environmental samples. Sep. Sci. Technol. 2018, 53, 1654-1665. [CrossRef]

13. Cyganowski, P. Synthesis of Adsorbents with Anion Exchange and Chelating Properties for Separation and Recovery of Precious Metals-A Review. Solvent Extr. Ion Exch. 2020, 38, 143-165. [CrossRef]

14. Mladenova, E.; Karadjova, I.; Tsalev, D.L. Solid-phase extraction in the determination of gold, palladium, and platinum. J. Sep. Sci. 2012, 35, 1249-1265. [CrossRef] [PubMed]

15. Vlašánková, R.; Sommer, L. Solid phase extraction and preconcentration for the determination of trace amounts of platinum group metals in environmental and biotic material a critical review. Chem. Pap. 1999, 53, 200-209.

16. Ehrlich, H.V.; Buslaeva, T.M.; Maryutina, T.A. Trends in Sorption Recovery of Platinum Metals: A Critical Survey. Russ. J. Inorg. Chem. 2017, 62, 1797-1818. [CrossRef]

17. Mokhodoeva, O.B.; Myasoedova, G.V.; Kubrakova, I.V. Sorption preconcentration in combined methods for the determination of noble metals. J. Anal. Chem. 2007, 62, 607-622. [CrossRef]

18. Sánchez, J.; Hidalgo, M.; Salvadó, V. The selective adsorption of gold (III) and palladium (II) on new phosphine sulphide-type chelating polymers bearing different spacer arms: Equilibrium and kinetic characterisation. React. Funct. Polym. 2001, 46, $283-291$. [CrossRef]

19. Iglesias, M.; Anticó, E.; Salvadó, V. Recovery of palladium(II) and gold(III) from diluted liquors using the resin duolite GT-73. Anal. Chim. Acta 1999, 381, 61-67. [CrossRef]

20. Slovák, Z.; Smrž, M.; Docekal, B.; Slováková, S. Analytical behaviour of hydrophilic glycolmethacrylate gels with bound thiol groups. Anal. Chim. Acta 1979, 111, 243-249. [CrossRef]

21. Chassary, P.; Vincent, T.; Guibal, E. Metal anion sorption on chitosan and derivative materials: A strategy for polymer modification and optimum use. React. Funct. Polym. 2004, 60, 137-149. [CrossRef]

22. Zuo, G.; Muhammed, M. Extraction of Noble Metals by Sulfur-Containing Reagents and Solvent Impregnated Resins. Solvent Extr. Ion Exch. 1995, 13, 879-899. [CrossRef]

23. Jyothi, R.K.; Lee, J.-Y.; Kim, J.-S.; Sohn, J.-S. Liquid-liquid extraction of platinum from acidic solutions-A review. Solvent Extr. Res. Dev. 2009, 16, 13-22.

24. Hubicki, Z.; Leszczyńska, M.; Łodyga, B.; Łodyga, A. Recovery of palladium(II) from chloride and chloride-nitrate solutions using ion-exchange resins with S-donor atoms. Desalination 2007, 207, 80-86. [CrossRef]

25. Nikoloski, A.N.; Ang, K.-L. Review of the Application of Ion Exchange Resins for the Recovery of Platinum-Group Metals From Hydrochloric Acid Solutions. Miner. Process. Extr. Met. Rev. 2014, 35, 369-389. [CrossRef]

26. Polakovičová, J.; Medved, J.; Streško, V.; Kubová, J.; Čelková, A. Spectrographic determination of gold in geological materials after preconcentration on Spheron-Thiol. Anal. Chim. Acta 1996, 320, 145-149. [CrossRef] 
27. Pyle, J.T.; Jacobs, W.D. Solvent Extraction of Platinum and Palladium with Derivatives of Dithiocarbamic Acid. Anal. Chem. 1964, 36, 1796-1799. [CrossRef]

28. Mueller, B.J.; Lovett, R.J. Determination of Pd and Co as Their Dithiocarbamate Complexes by Liquid Chromatography without Solvent Extraction. Anal. Lett. 1985, 18, 2399-2419. [CrossRef]

29. Diamantatos, A.; Verbeek, A. Method for the separation of platinum, palladium, rhodium, iridium and gold by solvent extraction. Anal. Chim. Acta 1977, 91, 287-294. [CrossRef]

30. Uheida, A.; Zhang, Y.; Muhammed, M. Extraction of Platinum(IV) with Nonylthiourea Dissolved in Chloroform from Hydrochloric Acid Media. Solvent Extr. Ion Exch. 2003, 21, 827-840. [CrossRef]

31. Ohto, K.; Furugou, H.; Yoshinaga, T.; Morisada, S.; Kawakita, H.; Inoue, K. Precious Metal Extraction with Thiol and Dithioether Derivatives of a Trident Molecule. Solvent Extr. Res. Dev. Jpn. 2017, 24, 77-88. [CrossRef]

32. Torgov, V.O. Sulphurous Extraction Agents for the Separation of Noble and Non-Ferrous Metals. Isot. Isot. Environ. Health Stud. 1984, 20, 352-359. [CrossRef]

33. Trokhimchuk, A.; Andrianova, E.; Losev, V. Interaction Peculiarities of Gold(III) with Silica Gels Containing Both Aminopropyl and Mercaptopropyl Surface Groups. Adsorpt. Sci. Technol. 2004, 22, 837-848. [CrossRef]

34. Shi, W.; Tao, S.; Yu, Y.; Wang, Y.; Ma, W. High performance adsorbents based on hierarchically porous silica for purifying multicomponent wastewater. J. Mater. Chem. 2011, 21, 15567-15574. [CrossRef]

35. Göktürk, G.; Delzendeh, M.; Volkan, M. Preconcentration of germanium on mercapto-modified silica gel. Spectrochim. Acta Part B At. Spectrosc. 2000, 55, 1063-1071. [CrossRef]

36. Khatib, I.; Parish, R. Insoluble ligands and their applications. J. Organomet. Chem. 1989, 369, 9-16. [CrossRef]

37. Venkatesan, K.; Srinivasan, T.; Rao, P.V. Cobalt-extraction studies on dithiocarbamate grafted on silica gel surface. Colloids Surf. A Physicochem. Eng. Asp. 2001, 180, 277-284. [CrossRef] 